\title{
Characteristics of Primary Open-Angle Glaucoma Patients in Dr. Soetomo General Hospital Surabaya
}

\author{
Sherly Yolanda ${ }^{1}$, Yulia Primitasari ${ }^{\star}$, Dewi Ratna Sari ${ }^{3}$
}

${ }^{1}$ Faculty of Medicine, Universitas Airlangga, Surabaya, Indonesia.

2Department of Ophthalmology, Faculty of Medicine, Universitas Airlangga/Dr. Soetomo General Hospital, Surabaya, Indonesia. ${ }^{3}$ Department of Anatomy and Histology, Universitas Airlangga, Surabaya, Indonesia.

\section{A B S T R A C T}

Introduction: This research aimed to describe the characteristics of primary openangle glaucoma (POAG) patients in Dr. Soetomo General Hospital Surabaya.

Methods: This was a descriptive study to determine the characteristics of POAG in 42 patients recruited from Ophthalmology Outpatient Clinic, Dr. Soetomo General Hospital, Surabaya, from March to June 2018. This study was conducted because the epidemiological data about characteristics of patients with POAG in Surabaya are not available yet.

Results: The ratio of male and female patients with POAG was 1:1, the largest age group of patients was 55-64 years old (38.10\%), in which a few patients had history of hypertension (45.24\%). Regression of visual acuity was the most common symptoms along with clinical sign of the patients $(78.57 \%)$, and the most common location of POAG was both eyes (69.05\%). Furthermore, the mean of visual acuity of patients with POAG was $0.38 \pm 0.36$, and the mean of intraocular pressure of patients with POAG was $22.22 \pm 9.24 \mathrm{mmHg}$.

Conclusion: POAG is generally bilateral disease that can occur in men and women with no differences with the largest age group of 55-64 years old, the most common symptom and clinical sign was regression of visual acuity.

*Correspondence: yulia_primitasari@yahoo.com

JUXTA: Jurnal Ilmiah Mahasiswa Kedokteran Universitas Airlangga

p-ISSN: 1907-3623; e-ISSN: 2684-9453

DOI: $10.20473 /$ juxta.V12I12021.6-9

Open access under Creative Commons Attribution-ShareAlike 4.0 International License (CC-BY-SA)

\section{ARTICLE INFO}

\section{Article history:}

Received 6 November 2020

Received in revised form 24

November 2020

Accepted 7 December 2020

\section{Keywords:}

Primary open-angle glaucoma, Characteristics,

Visual acuity, Intraocular pressure. 


\section{Introduction}

Glaucoma is the third leading cause of blindness worldwide after cataracts and refractive disorders. ${ }^{1}$ According to $\mathrm{WHO}$, the estimated number of cases of blindness due to glaucoma is 4.5 million of all blindness. ${ }^{1}$ Based on Sense Health Survey in 1993-1996, 1.5\% of Indonesian population had blindness with a prevalence of blindness due to glaucoma by $0.2 \%{ }^{2}$

Glaucoma is a type of optic neuropathy characterized by loss of retinal ganglion cells, optic nerve head, and loss of visual field where intraocular pressure was thought to be a major risk factor. ${ }^{3,4}$ Glaucoma can be classified as primary glaucoma, secondary glaucoma, and congenital glaucoma. Primary open-angle glaucoma (POAG) is the most common form of glaucoma and affects 44.1 million individuals worldwide. ${ }^{4}$ POAG tends to be idiopathic. The patient has gradual visual field loss but does not appear with acute pain, red eyes, or rapid visual loss because it is characterized by closed angle glaucoma. ${ }^{5}$

Although intraocular pressure remains an important risk factor for glaucoma, other factors can also affect glaucoma. Recently, blood pressure can play a role in the occurrence of glaucoma. ${ }^{6}$ Several studies have shown that systemic hypertension is a risk factor for glaucoma. ${ }^{7}$ In addition, several studies have suggested an association between intraocular pressure and hypertension through several mechanisms. ${ }^{8,9}$

Epidemiological data regarding the number of POAG patients in Surabaya are not available yet. Based on the previous explanation, this study was conducted to identify the characteristics of POAG patients in Dr. Soetomo General Hospital Surabaya in the period of January 2015 to December 2017.

\section{Methods}

This study used a descriptive research design and was conducted at Outpatient Clinic of Dr. Soetomo General Hospital Surabaya and performed in March to June 2018. The number of subjects were 42 patients. The population in this study were all POAG patients at Outpatient Clinic of Dr. Soetomo General Hospital Surabaya. The subjects in this study were POAG patients who were first registered at Outpatient Clinic of Dr. Soetomo General Hospital Surabaya in the period of January 2015 to December 2017 above the age of 34 years old. This study used secondary data in the form of medical records. This study had received ethical approval from Research and Development Department of Dr. Soetomo General Hospital Surabaya. Data obtained from medical records were processed using Statistical Product and Service Solution (SPSS) version 20 and presented in table forms.

\section{Results}

In this study, a total of 42 patients were diagnosed with a diagnosis of POAG.
Table 1. Characteristics of primary open-angle glaucoma patients.

\begin{tabular}{|c|c|c|}
\hline Variable & Frequency & Percentage \\
\hline \multicolumn{3}{|l|}{ Age Category } \\
\hline $35-44$ years old & 3 & $7.14 \%$ \\
\hline 45-44 years old & 14 & $33.33 \%$ \\
\hline 55-64 years old & 16 & $38.10 \%$ \\
\hline $65-74$ years old & 9 & $21.43 \%$ \\
\hline \multicolumn{3}{|l|}{ Gender } \\
\hline Male & 21 & $50.00 \%$ \\
\hline Female & 21 & $50.00 \%$ \\
\hline \multicolumn{3}{|l|}{$\begin{array}{l}\text { Hypertension } \\
\text { history }\end{array}$} \\
\hline Yes & 19 & $45.24 \%$ \\
\hline No & 23 & $54.76 \%$ \\
\hline \multicolumn{3}{|l|}{ Bilaterality } \\
\hline Oculi dextra dinistra & 29 & $69.05 \%$ \\
\hline Oculi dextra & 5 & $11.90 \%$ \\
\hline Oculi sinistra & 8 & $19.05 \%$ \\
\hline \multicolumn{3}{|l|}{$\begin{array}{l}\text { Symptoms and } \\
\text { clinical sign }\end{array}$} \\
\hline Visual regression & 33 & $78.57 \%$ \\
\hline Halo & 19 & $45.24 \%$ \\
\hline Eye pain & 11 & $26.19 \%$ \\
\hline Red eye & 11 & $26.19 \%$ \\
\hline Throbbing & 10 & $23.81 \%$ \\
\hline Dazzled & 7 & $16.67 \%$ \\
\hline Nausea/vomit & 5 & $11.90 \%$ \\
\hline Dizzy & 5 & $11.90 \%$ \\
\hline Headache & 4 & $9.52 \%$ \\
\hline Others & 9 & $21.48 \%$ \\
\hline
\end{tabular}

Table 1 shows that the distribution of male and female patients has the same percentage, the largest distribution of the patients was in the age group of 55-64 years old, there were more patients who had no history of hypertension, the patients most experienced POAG in both eyes, and the most common symptom and clinical sign was regression of visual acuity.

Patients who came to Outpatient Clinic of Dr. Soetomo General Hospital Surabaya got a visual examination. Table 2 is the visual acuity of 42 patients, there were 84 eyes of POAG patients at Outpatient Clinic of Dr. Soetomo General Hospital Surabaya from January 2015 to December 2017 when they first arrived.

Table 2. Patient frequency distribution based on visual acuity.

\begin{tabular}{ccc}
\hline Visual Acuity & Frequency & Percentage \\
\hline $6 / 6-6 / 18(1.00-0.33)$ & 31 & $36.90 \%$ \\
$6 / 18-6 / 60(0.33-0.10)$ & 16 & $19.05 \%$ \\
$6 / 60-3 / 60(0.10-0.05)$ & 10 & $11.90 \%$ \\
$3 / 60-$ LP+ (0.05-LP+) & 19 & $22.62 \%$ \\
LP- & 8 & $9.52 \%$ \\
\hline
\end{tabular}

Table 2 shows the highest visual acuity was in the range of $6 / 6-6 / 18$. The visual mean of the patients was $0.38 \pm 0.36$. The highest visual acuity was $6 / 6$ and the lowest vision was LP.

Table 3 is the value of intraocular pressure from 42 POAG patients when they first arrived with a total of 83 eyes where one eye of the subjects had Ptysis bulbi. 
Table 3. Distribution of patient frequency based on intraocular pressure.

\begin{tabular}{ccc}
\hline $\begin{array}{c}\text { Intraocular Pressure } \\
(\mathbf{m m H g})\end{array}$ & Frequency & Percentage \\
\hline$<11$ & 6 & $7.23 \%$ \\
$11-21$ & 42 & $50.60 \%$ \\
$22-30$ & 18 & $21.69 \%$ \\
$>30$ & 17 & $20.48 \%$ \\
\hline
\end{tabular}

Table 3 shows the highest value of intraocular pressure was in the range of $11-21 \mathrm{mmHg}$. The mean intraocular pressure of the patients was $22.22 \pm 9.24$ $\mathrm{mmHg}$. The highest intraocular pressure was $50.60 \mathrm{mmHg}$ and the lowest intraocular pressure was $5.90 \mathrm{mmHg}$.

\section{Discussion}

POAG is a chronic, progressive, anterior optic neuropathy that is accompanied by atrophy in cup-to-disc, decreased field of view, and systemic conditions. Increased intraocular pressure is the main risk factor for the occurrence of POAG. ${ }^{10}$ It is generally stated that higher intraocular pressure will be more likely to increase the progression of optic disc damage. ${ }^{11}$ This study obtained the most age range results in the 55-64 years old age group. This result is in line with a study conducted in Department of Ophthalmology, Jawaharlal Nehru Medical College, DMIMSDU, Sawangi (M), Wardha, Maharashtra (India) where the highest age group was in the 55-64 years old age group with a $30 \%$ percentage. ${ }^{12}$ This study also obtained the mean age of $56.81 \pm 9.18$ years. A study at Tohoku University Hospital found that the mean age of POAG patients was $63.4 \pm 12.4$ years. ${ }^{13}$ It is known that the factor of increasing age has more opportunities to make people suffer from POAG. It is known that POAG is a disease with chronic and progressive optic nerve damage which has slow progressivity and asymptomatic. POAG occurs due to the inhibition of aqueous humor outflow according to degenerative changes of trabecular meshwork. ${ }^{10,14}$

Furthermore, a study in Oman regarding the prevalence and risk factors for glaucoma showed that the comparison between men and women was 1.01:1.15 A study in Bihar (India) on the characteristics of glaucoma obtained a comparison between men and women of 1.03:1. ${ }^{16}$ Those study were similar with the results of this study where the sex ratio of men and women was 1:1. Other studies which supported this study reported that there was no significant differences by sex. ${ }^{12}$ It can be concluded that POAG can affect all genders.

Intraocular pressure remains an important risk factor for glaucoma, but other factors can also affect glaucoma. Several studies have shown that systemic hypertension is a risk factor for glaucoma. ${ }^{7}$ This study investigated the history of hypertension with the incidence of POAG. This study showed that POAG patients who did not have a history of hypertension was greater than the patients who had no history of hypertension. The direct correlation between blood pressure, intraocular pressure, and damage of the optic nerve papil were still unclear until now. ${ }^{7}$ This data was based on the history taking of hypertension in which not all patients were aware about their history of hypertension and other diseases that could be the risk factors of glaucoma. In order to get the exact data, it is necessary to measure blood pressure.

POAG is generally a bilateral disease that attacks adulthood. At least one eye must have typical damage to the optic nerve or changes in visual field characteristics, POAG without obvious abnormalities, and the absence of other glaucoma-causing abnormalities. ${ }^{10}$ A study conducted by Joeng, et al. (2015) showed that $60.9 \%$ of the patients had glaucoma in both eyes (bilateral). ${ }^{17}$ In addition, a study conducted by Putri, et al. (2014) obtained 66.67\% of POAG patients in Sanglah General Hospital in Denpasar had POAG in both eyes. ${ }^{18}$ In this study, the location of POAG was most common in both eyes (bilateral).

POAG is usually described as a hidden disease, progressive, and usually occurs in both eyes. POAG rarely shows typical or specific symptoms to the patient until the final phase of the disease. Patients who come to the hospital often complain about decreasing visual acuity when they first come for treatment. Examinations often get an increase of intraocular pressure in the patient. ${ }^{10} \mathrm{~A}$ study by Shakya-Vaidya, et al. (2014) in Nepal had the results that most POAG patients had a visual range of $6 / 6-6 / 18 .{ }^{19}$ A study by Zhao Yang, et al. (2015) at Ophthalmologic Hospital, China received a mean value of $0.34 \pm 0.35 .^{20}$ This study obtained the results of the visual range were normal to mild visual impairment with a mean visual acuity of $0.38 \pm 0.36$. The results showed that POAG patients had the most normal visual acuity to mild visual impairment. It was because POAG slowly affected peripheral vision (visual field) where visual acuity could be normal and furthermore central vision disturbance could occur in the final stage of the disease..$^{19}$ Thus, the number of glaucoma patients with normal visual acuity have possibility in decreasing of visual field. Unfortunately, this study did not take data about the visual field of glaucoma patients.

The pathophysiology of POAG cannot be separated from the important mechanism of increasing intraocular pressure. Intraocular pressure is determined by the velocity of the formation of aqueous humor by the ciliary body and the obstacles that occur in trabecular meshwork. ${ }^{14}$ The results of a study conducted by Yokoyama, et al. (2015) at Tohoku University Hospital received a range of intraocular pressure values of $11-20 \mathrm{mmHg} .{ }^{13}$ In this study, the highest intraocular pressure results of POAG patients were found in the normal range. This is presumably because the patient had previously undergone treatment therapy to reduce intraocular pressure at the first level of health services, considering that Dr. Soetomo General Hospital Surabaya was the last referral hospital. However, the data about the history of treatment were not listed. 


\section{Conclusion}

POAG is generally bilateral disease that can occur in men and women with no differences with the largest age group of 55-64 years old, the most common symptoms and clinical signs was regression of visual acuity.

\section{CONFLICT OF INTEREST}

The author stated there is no conflict of interest in this study.

\section{REFERENCES}

1. Organization WH. Visual Impairment and Blindness. Geneva: World Health Organization, 2009.

2. Indonesia DKR. Hasil Survei Kesehatan Indera Penglihatan dan Pendengaran 1993-1996. In: Indonesia DKR, (ed.). Jakarta: Direktorat Jenderal Pelayanan Kesehatan, 1998.

3. Ilyas S. Glaukoma (Tekanan Bola Mata Tinggi). Jakarta: Sagung Seto, 2007.

4. Tham YC, Li X, Wong TY, Quigley HA, Aung T and Cheng CY. Global Prevalence of Glaucoma and Projections of Glaucoma Burden through 2040: A Systematic Review and Meta-Analysis. Ophthalmology. 2014; 121: 2081-90.

5. Caprioli J and Coleman AL. Blood Pressure, Perfusion Pressure, and Glaucoma. American Journal of Ophthalmology. 2010; 149: 704-12.

6. He Z, Vingrys AJ, Armitage JA and Bui BV. The Role of Blood Pressure in Glaucoma. Clinical \& Experimental Optometry. 2011; 94: 133-49.

7. Cherecheanu AP, Garhofer G, Schmidl D, Werkmeister $\mathrm{R}$ and Schmetterer L. Ocular Perfusion Pressure and Ocular Blood Flow in Glaucoma. Current Opinion in Pharmacology. 2013; 13: 36-42.

8. Deokule $S$ and Weinreb RN. Relationships among Systemic Blood Pressure, Intraocular Pressure, and OpenAngle Glaucoma. Canadian Journal of Ophthalmology Journal Canadien d'ophtalmologie. 2008; 43: 302-7.

9. Langman MJ, Lancashire RJ, Cheng KK and Stewart PM. Systemic Hypertension and Glaucoma: Mechanisms in Common and Co-Occurrence. The British Journal of Ophthalmology. 2005; 89: 960-3.
10. Stamper RL, Lieberman MF and Drake MV. Chapter 17

- Primary Open Angle Glaucoma. In: Stamper RL, Lieberman MF and Drake MV, (eds.). Becker-Shaffer's Diagnosis and Therapy of the Glaucomas (Eighth Edition). Edinburgh: Mosby, 2009, p. 239-65.

11. Liesegang $T$, Skuta $G$ and Cantor L. Introduction to Glaucoma: Terminology, Epidemiology and Heredity Basic and Clinical Science Course of Glaucoma. San Francisco: American Academy of Ophthalmology, 2005, p. 201-302. 12. Tidake $P$ and Sharma $S$. Clinical Profile and Management of Primary Open-Angle Glaucoma Patients above 40 Years: A Rural Hospital-Based Study. Journal of Datta Meghe Institute of Medical Sciences University. 2017; 12: 1-6.

13. Yokoyama $\mathrm{Y}$, Maruyama $\mathrm{K}$, Konno $\mathrm{H}$, et al. Characteristics of Patients with Primary Open Angle Glaucoma and Normal Tension Glaucoma at a University Hospital: A Cross-Sectional Retrospective Study. BMC Research Notes. 2015; 8: 360.

14. Ilyas S. IImu Penyakit Mata Untuk Dokter Umum dan Mahasiswa Kedokteran. Sagung Seto, 2002.

15. Khandekar R, Jaffer MA, Al Raisi A, et al. Oman Eye Study 2005: Prevalence and Determinants of Glaucoma. Eastern Mediterranean Health Journal = La revue de sante de la Mediterranee orientale = al-Majallah al-sihhiyah lisharq al-mutawassit. 2008; 14: 1349-59.

16. Shekhar J, Akhaury RK, Kumar R and Verma N. Glaucoma Pattern in Central Bihar-A Cross-Sectional Retrospective Study. 2010.

17. Jeong D, Sung KR and $\mathrm{Na} \mathrm{JH}$. Comparison of Clinical Characteristics and Progression Rates of Bilaterally and Unilaterally Progressing Glaucoma. Korean Journal of Ophthalmology: KJO. 2015; 29: 40-6.

18. Putri $P$, Sutyawan IWE and Triningrat $A$. Karakteristik Penderita Glaukoma Primer Sudut Terbuka dan Sudut Tertutup di Divisi Glaukoma di Poliklinik Mata Rumah Sakit Umum Pusat Sanglah Denpasar Periode 1 Januari 2014 hingga 31 Desember 2014. 2014.

19. Shakya-Vaidya S, Student P, Umesh R, Am G and Grjibovski A. Visual Status in Primary Open Angle Glaucoma: A Hospital Based Report from Nepal. Journal of Kathmandu Medical College. 2014; 3.

20. Zhao Y, Fu JL, Li YL, Li P and Lou FL. Epidemiology and Clinical Characteristics of Patients with Glaucoma: An Analysis of Hospital Data between 2003 and 2012. Indian Journal of Ophthalmology. 2015; 63: 825-31. 